\title{
NMR を牽引する超伝導・極低温技術
}

独立行政法人 理化学研究所 NMR 施設長

前田 秀明

NMR は MRI と共に，広く一般に使用されている超伝導 装置で, 有機化学, 天然物化学, 生化学や材料科学など 色々な分野で使用されています。(独)理化学研究所は 10 台以上の高磁場 NMR からなる世界最大級の NMR 施設を 持ち, タンパク質の立体構造の決定や, 創薬に重要なリー ド化合物 (薬刻候補) の選別, 生命維持のための代謝入力 ニズムの研究などに活用しています。ここでは, NMR と 超伝導・極低温技術の結びつきについて二つだけ述べてみ たいと思います。

一つ目は, NMRの磁場強度についてです。NMR では, 磁場が高い程，スペクトルの分解能や SN 比が高くなりま す。NMRの進歩は高磁場化の歴史です。70 年代に NbTi の NMR 磁石が開発され，80 年代には $\mathrm{Nb}_{3} \mathrm{Sn}$ による $12 \mathrm{~T}$ クラス（500 MHz）の磁石が開発されました。更に，Ti 添加 $\mathrm{Nb}_{3} \mathrm{Sn}$ 線材や超流動へリウム冷却の導入により, 95 年には 19 T クラス (800 MHz) の NMR 磁石が実現しま した。現在では23.5 T (1 GHz) の磁石が稼働していま す。このように NMR の歴史は，超伝導マグネットの歴史 と軌を一にしています。超伝導マグネット技術開発の成果 をうまく取り入れることで, NMRの高磁場化が実現して きたといってもよいと思います。NMR では高磁場化と共 に，新しい応用が次々に切り開かれてきました。低温超伝 導の NMR 磁石では $23.5 \mathrm{~T}(1 \mathrm{GHz})$ が限界です。今年の 2 月にイスラエルで A Foresight Workshop という NMR の学会が開かれました。この学会は, 規模は小さいです が, 世界中から高名な研究者が集まり，今後の NMR 技術 について議論をしました。非常に印象的だったのは, 将来 を左右するキー技術として超高磁場 NMR 磁石が取り上げ られ，「28 T NMR (1.2 GHz) は実現できるのか」という テーマで熱心な議論が展開されたことです。私も，開発中 の BSCCO や REBCO による NMR を紹介し, REBCO を利 用すれば，35 T (1.5 GHz) の NMR 磁石が実現できると 述べましたが，非常に大きな反響を呼びました。 REBCO コイルは高温超伝導マグネット技術でも最先端のフロンテ イアです。NMRの更なる高磁場化の可否は, 超伝導・極 低温技術研究者の肩にかかっているというわけです。愉快 で，やりがいのある話ですね。
二つ目に述べたいのは, NMR 磁石のユーザーフレンド リー性です。NMR 磁石は低温・超電導技術になじみのな い人が利用しますから, 高いユーザーフレンドリー性が要 求されます。最大の障害はクエンチですが, NMR は永久 電流で運転されており意外なほどクエンチの発生は少ない のが実状です。数十台の NMR を 1 年間運転して, クエン チは年間に 1 件あるかないかというレベルです。液体へ リウムの注液は数力月毎でよいので, 中型の液化機 1 台 で数十台の NMR に必要な液体ヘリウムを賄うことができ ます。この意味で, 通常は液体へリウムによる不便さは, ほとんど感じません。但し, 昨今の, 液体へリウムの不 足は，私たちの NMR 施設が液体ヘリウムの基盤の上に立 っていることを改めて教えてくれました。MRIでは小型 冷凍機でヘリウム蒸発を抑制していますが, NMR は振動 を嫌うので $4 \mathrm{~K}$ 冷凍機や，ヘリウムフリー（冷凍機間接冷 却）などの最新の冷却技術は敬遠される傾向にあります。 今回のヘリウムの不足を契機に，わが国からこの種の技術 が育つことを期待したいところです。ユーザーフレンドリ 一という意味では, 最近の NMR 磁石は磁気シールド技術 が進んでおり，磁石の傍でも漏れ磁場は無視できます。む しろ, 高磁場装置で磁石が巨大化することが問題になって います。REBCO を利用すれば液体へリウム冷却で磁石も コンパクトにできるので, ユーザーフレンドリー性が一層 高まります。このように, 最新の低温工学・超伝導技術を 利用すれば，まだまだ NMR 磁石のユーザーフレンドリー 性を高めることができます。この面からの低温工学・超伝 導技術の貢献が期待されます。

以上述べてきたように, NMR は低温工学・超伝導技術 と共に歩んできました。NMR 装置のイノベーションは, 多くが低温工学・超伝導技術によると言っても過言ではな いと思います。但し, 最近では低温超伝導を用いた装置技 術の進歩はほぼ飽和してきています。これからのイノべー ションは, 高温超伝導技術や最新の冷却技術をどのように 活用できるかにかかっていると思います。この点で, 私た ちは低温工学・超電導学会の今後の活動に大変期待してい ます。 